\title{
Acquisitions, Mergers, Joint-Ventures, Alliances, Partnerships and other Business Combinations, a study of TATA Sons, their journey, impacts and strategies for the Airline Industry
}

\author{
Shaheed Khan', Freeda Maria Swarna M², R. Kannan³, S. Praveen Kumar ${ }^{3}$ \\ Research Scholar, Centre for Tourism and Hotel Management, Madurai Kamaraj University, Madurai, India ${ }^{1}$ \\ Research Scholar, Centre for Tourism and Hotel Management, Madurai Kamaraj University, Madurai, India ${ }^{2}$ \\ Professor and Director, Centre for Tourism and Hotel Management, Madurai Kamaraj University, Madurai, India ${ }^{3}$ \\ Assistant Professor, Centre for Tourism and Hotel Management, Madurai Kamaraj University, Madurai, India ${ }^{4}$
}

\begin{abstract}
Aviation Industry has held its stead and ensured corporate business across the world. India saw the growth of airlines from the beginning of the twentieth century albeit, in the private sector, India also witnessed Nationalization followed by privatization. With a multitude of domestic and global players, aviation in India grew leaps and bounds. Many private airlines wound up on various accounts, many were born as well. The Government of India ensured that Air India and its subsidiaries which were successful till the 1970s and were losing steam on account of bureaucratic and political apathy was funding the behemoth, which turned out to be a loss-making enterprise. The world of aviation has seen plenty of Acquisitions, Mergers, Joint-ventures, Alliances, Partnerships and other business combinations as researched and studied by Prof. Benjamin Gomes-Casseres in his Remix Strategy. The Research paper is a work in progress which is focusing on the dynamics of what the TATA Sons are doing to ensure a revert back to the business that they originally founded in 1932.
\end{abstract}

Keywords: Acquisitions, Mergers, Joint-Ventures, Alliances, Partnerships, Value-creation

\section{INTRODUCTION}

Wind, Sand, and a dream flight brought Wilbur and Orville Wright to Kitty Hawk, North Caroline and after four years of scientific experimentation, they achieved the first successful aeroplane flight on December $17^{\text {th }}, 1903$ (National Park Service); a momentous occasion in contemporary world history; at the same time, a child in the mother's womb was awaiting an arrival into the world and it did see the light of the world on $29^{\text {th }}$ July 1904 . Sure, the later date may not ring an immediate bell in our minds, the kid, a lad grew up and made a date that Indian Aviation history recorded, for, on $15^{\text {th }}$ October 1932, the first-ever flight in the Indian subcontinent from Karachi's Drigh Road Aerodrome to Bombay's Juhu Airstrip via Ahmedabad was piloted by him, the flight carried 25 kilograms of four-anna airmail letters (Pal, 2017). By now you would have guessed it right, yes, it is Jehangir Ratanji Dadabhoy Tata, better known to every Indian, nay the world as JRD Tata. Yes, airlines in India had arrived; with JRD getting to fly from Karachi to Bombay at the age of twenty-eight. Though not the first to register (TATA.com 2021), he was the first Indian to pass out India's first flying club in Bombay, the Aero Club of India and Burma (Pal, 2017), with "No. 1" endorsed on his flying licence. And so it came to pass that India's first pilot was to pour most of his creative genius into building an airline for his country, giving his nation wings. In fact (Business Standard, 2013), JRD set up India's first airline, Tata Airlines, in 1932. In 1946, it was renamed Air -India. Two years later, Tata set up Air-India International in collaboration with the government after the Indian Government acquired a 49\% equity in the company and fully nationalized the airline pursuant to the Air Corporation Act of 1953 (NDA, 2016); a company (Alikhan, 2017) that once inspired Singapore Airlines (and Cathay Pacific). The Singapore Authorities shortlisted the world's best airlines and finally zeroed in one of them, was Air-India. Air-India, with a 'hyphen' in the middle; which (the hyphen) was permanently removed (Wickstead, 2016) in May 2004. We have to realize that in 1953, the Air Corporation Act of 1953 ensured that, seven domestic airlines: Deccan Airways (Jointly owned by the Nizam of Hyderabad and TATAs founded in 1945); Airways India, Bharat Airways, Himalayan Aviation, Kalinga Airlines (Burns, 1997), Indian National Airways and Air Services of India were merged to form the new domestic national carrier Indian Airlines Corporation (Agarwal, 2011). 


\title{
International Advanced Research Journal in Science, Engineering and Technology
}

\author{
Vol. 8, Issue 8, August 2021
}

\section{DOI: 10.17148/IARJSET.2021.8867}

If the histrionics of JRD were recorded in the Aviation history of India, an event of 1911 (India Today, 2016) vintage when the first airmail flight was piloted by French pilot Henri Pequet, who flew 6,500 letters a distance of five miles from Allahabad to Naini in the present state of Uttar Pradesh. pushed back the history of Indian Civil Aviation even further. Whether it was Henri Pequet or JRD, little did they realize the Aviation world which they started as humble beginnings; would reach the heights, where India (Economic Times, 2018) had become the third-largest civil aviation market (by 2020 ) and $86 \%$ of the market share was with the private sector. A glance at the Flight Radar satellite picture (Fig. 1) of aircraft in the Indian skies. It is a clear picture, of the number of Domestic and International players who are in the Aviation/airlines business in India. The research paper is a focus on how the industry has grown; and there has been 'value creation' through Alliances, partnerships, acquisitions, mergers and joint ventures (JV); which are no longer exceptions to business, as they are part of the core strategy (Gomes-Casseres, Benjamin, 2015). How then did airlines evolve in India and grow to one of the biggest Aviation Economies of the World? A look at the milestones in Aviation history will help us to assuage the eventful happenings that led to phenomenal value creation.

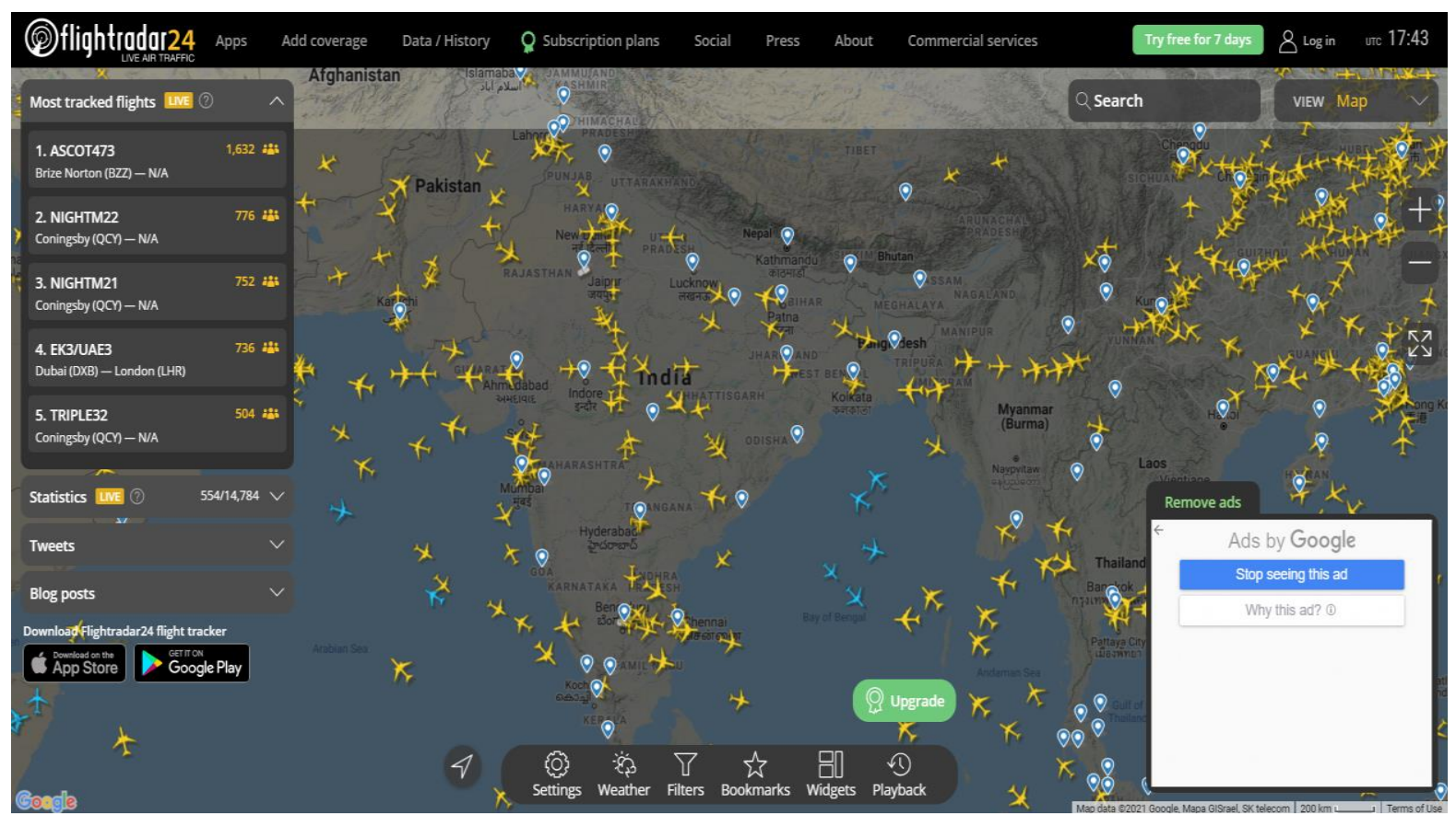

Fig. 1: Flights in the Indian skies, on 5th July 2021 at 23:12. Source: https://www.flightradar24.com/21.49,82.61/5

From 1953 till 2020, the civil aviation industry has gone through phenomenal changes, changes that can be considered as important landmarks, that has helped catapult the aviation industry to its current heights. Post-1953, what were the milestones till 2020? Understanding the milestones will help one to understand the growth, evolution, opportunities and challenges that Indian civil aviation went through; which will provide us with a peek into the nuances of 'value creation.' Fast forward three decades, and we get the following milestones (NDA, 2016) in Indian Civil Aviation which was helping in the build-up for Alliances, Partnerships, Collaborations, M\&As, JVs:

\begin{tabular}{|l|l|}
\hline Year & Activity \\
\hline 1981 & Vayudoot Airlines (Government of India) started operations \\
\hline 1985 & Pawan Hans Helicopters Limited (PHHL) started operations \\
\hline 1986 & Private Players permitted to operate as Air Taxi Operators (ATO) \\
\hline 1990 & $\begin{array}{l}11^{\text {th }} \text { April 1990, the Government of India adopted the Open-sky policy and allowed ATOs to operate } \\
\text { flights from any airport, both on a charter and a non-charter basis and to decide their flight schedules, } \\
\text { cargo and passenger fares. This move marked the reversal of a process that began in August 1953 when } \\
\text { eight private airlines were nationalized (Pranjoy Guha Thakurta, 1990). East-West (APAO, 2012) } \\
\text { Airlines became the first National Private Airline to operate in India after almost thirty-seven years of } \\
\text { Government Airlines. }\end{array}$ \\
\hline 1991 & Sahara Airlines started operations (September 20, 1991) \\
\hline 1993 & Jet Airways started operations \\
\hline 1994 & Air Corporation Act of 1953 was repealed. ATOs allowed operating as Scheduled Airlines \\
\hline
\end{tabular}


International Advanced Research Journal in Science, Engineering and Technology

Vol. 8, Issue 8, August 2021

DOI: 10.17148/IARJSET.2021.8867

\begin{tabular}{|c|c|}
\hline 1995 & $\begin{array}{l}\text { Modiluft, Damania Airways, East-West Airlines, NEPC, Sahara Airlines, Archana Airways, Jet Air } \\
\text { granted Scheduled Airlines status }\end{array}$ \\
\hline 1997 & Damania Airways, Modiluft, East-West Airlines, NEPC shut down operations. Jet and Sahara continue \\
\hline 2000 & Sahara Airlines rebranded as Air Sahara \\
\hline 2003 & Air Deccan Starts operations as India's first Low-Cost Carrier (LCC) \\
\hline 2004 & $\begin{array}{l}\text { June: GoAir starts operations as an LCC } \\
\text { Jet and Sahara allowed to fly to SAARC countries, started with flights to Sri Lanka (MoCA, Annual } \\
\text { Report 2003-04). } \\
\text { December: Airlines with five years of continuous operations and a minimum of twenty aircraft permitted } \\
\text { to fly scheduled services to International destinations } \\
\text { Kingfisher, SpiceJet, Indigo, Go Air and Paramount Airways start operations }\end{array}$ \\
\hline 2005 & $\begin{array}{l}\text { Indian Airlines rebranded as Indian. The Indian Government designated Air India, Indian Airlines, Jet } \\
\text { Airways and Air Sahara to operate International services } \\
\text { May: Kingfisher Airlines launches Full-Service Carrier (FSC) } \\
\text { Spice Jet commenced operations as LCC }\end{array}$ \\
\hline 2006 & August: Indigo started operations as LCC \\
\hline 2007 & $\begin{array}{ll}\text { 1. } & \text { Civil Aviation Consolidation: } \\
\text { 2. } & \text { Air India and India Airlines merge } \rightarrow \text { Air India } \\
\text { 3. } & \text { Jet Airways acquires (13 }{ }^{\text {th }} \text { April for INR } 1,450 \text { Crores) Air Sahara } \rightarrow \text { Jet Lite } \\
\text { 4. } & \text { Kingfisher acquires (June, for INR } 1000 \text { Crores, } 46 \% \text { stake) Air Deccan } \rightarrow \text { Simplifly Deccan }\end{array}$ \\
\hline 2008 & Simplifly Deccan rechristened as Kingfisher Red \\
\hline 2010 & SpiceJet starts International Operations \\
\hline 2011 & $\begin{array}{l}\text { Indigo Operates International flights } \\
\text { Kingfisher exits LCC segment (Kingfisher Red shuts operations) }\end{array}$ \\
\hline 2012 & $\begin{array}{l}\text { Foreign Direct Investment (FDI), the Government of India allows Foreign Airlines to hold a } 49 \% \text { stake } \\
\text { in scheduled and non-scheduled air transport services. Non-Resident Indians (NRI) permitted to hold } \\
100 \% \text { equity in Airlines }\end{array}$ \\
\hline 2013 & Singapore-based Tiger Air enters into an Interline agreement with SpiceJet \\
\hline 2014 & $\begin{array}{l}\text { Air Asia (a JV between TATA Sons, Malaysia's Air Asia Berhard and Arun Bhatia's Telestra } \\
\text { Tradeplace) and Vistara (a JV between TATA Sons and Singapore Airlines) enter the Indian Skies. } \\
\text { Etihad Airways of Abu Dhabi purchases } 24 \% \text { stake in Jet Airways }\end{array}$ \\
\hline 2015 & Indigo launches one of the Larger IPOs in India History \\
\hline 2016 & Jet Airways to merge with Jet Lite and exit the LCC segment completely \\
\hline 2019 & April Jet Airways Suspended its flights (Gandhi, 2020) \\
\hline
\end{tabular}

TABLE 1: Milestones in Indian Civil Aviation

It is clear from the milestones (TABLE 1) that, Indian Civil Aviation has made efforts to collaborate, create alliances, have JVs, create opportunities for Acquisitions, Mergers, Synergy and Integration and move towards profitability. The case studies will provide opportunities for one to understand if the frameworks of Remix Strategy as provided by GomesCasseres, Benjamin (2015) worked overall from a Business and Corporate or failed because of other reasons. The three laws of Business Combinations offer a simple (Gomes-Casseres, Benjamin, 2016), but powerful, framework to help in business decision making and they are as follows:
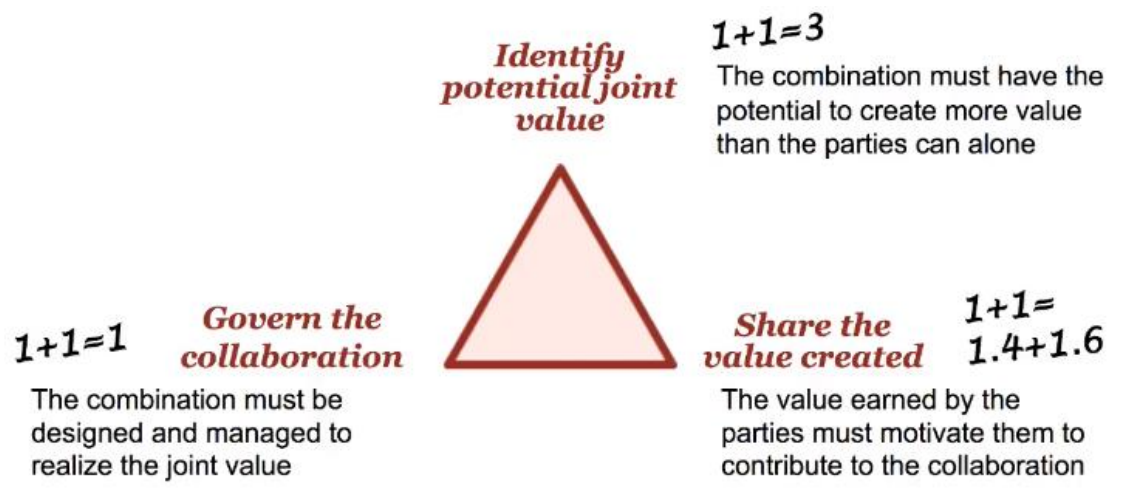

Fig.2 The Three Laws of Business Combinations (Gomes-Casseres, Benjamin, 2015) 
International Advanced Research Journal in Science, Engineering and Technology

Vol. 8, Issue 8, August 2021

DOI: $10.17148 /$ IARJSET.2021.8867

\begin{tabular}{|l|l|l|l|}
\hline The law & The primary Strategy & The focus & The deep-dive \\
\hline $\begin{array}{l}\text { First Law } \\
\mathbf{1 + 1 = 3}\end{array}$ & $\begin{array}{l}\text { The value created by the } \\
\text { Combination should exceed the total } \\
\text { value that would be generated by the } \\
\text { players acting alone. }\end{array}$ & $\begin{array}{l}\text { Which elements from } \\
\text { each business need to be } \\
\text { combined to create joint } \\
\text { value? }\end{array}$ & $\begin{array}{l}\text { focus on value creation } \\
\text { in the market }\end{array}$ \\
\hline $\begin{array}{l}\text { Second Law } \\
\mathbf{1 + 1 = 1}\end{array}$ & $\begin{array}{l}\text { The combination must be designed } \\
\text { and managed to realize this joint } \\
\text { value }\end{array}$ & $\begin{array}{l}\text { Which partners best fit } \\
\text { our strategic goals? How } \\
\text { should we manage the } \\
\text { integration? }\end{array}$ & $\begin{array}{l}\text { focus on the management } \\
\text { of risk and uncertainty } \\
\text { inherent in such } \\
\text { combinations }\end{array}$ \\
\hline $\begin{array}{l}\text { Third Law } \\
\mathbf{1 + 1 =} \\
\mathbf{1 . 4 + 1 . 6}\end{array}$ & $\begin{array}{l}\text { The Value earned by the parties must } \\
\text { motivate them to contribute to the } \\
\text { collaboration }\end{array}$ & $\begin{array}{l}\text { How will we share the } \\
\text { joint value created? Will } \\
\text { the returns shift over } \\
\text { time? }\end{array}$ & $\begin{array}{l}\text { It is about value sharing } \\
\text { over a time frame. It is } \\
\text { about how do the entities } \\
\text { divide and share the joint } \\
\text { value created }\end{array}$ \\
\hline
\end{tabular}

TABLE 2: The Three Laws of Business Combinations

Thence, how would the organizations ensure to "create value" for themselves by juxtaposing the three laws of business combinations; which will ensure success for the business, the combination, the enterprise as a whole? The eleven approaches discussed by the Remix Strategy are apt for an understanding.

\begin{tabular}{|c|c|c|c|}
\hline $\begin{array}{l}\text { All organizations seek to } \\
\text { create value by } \\
\text { combining or } \\
\text { repurposing resources } \\
\rightarrow \rightarrow\end{array}$ & Acquisitions & Outsourcing & Co-development \\
\hline Joint Ventures & Comarketing & Licensing & Alliances \\
\hline Ecosystems & Consortia & Supplier Networks & Open Innovation \\
\hline
\end{tabular}

TABLE 3: Eleven Approaches to Remix Strategy (Gomes-Casseres, Benjamin, 2015)

If these were the choices of a construct available for the airlines in India, then there was an opportunity, considering that almost more than three decades, the Government Airlines had ruled the skies. It was a war in another geography and minority Government at the Centre in India, and the new Government that came to power that was responsible for the Indian Civilian skies to be thrown open to a multitude of players. Well, the war was the one that Iraqi President Saddam Hussein brought about with the invasion of Kuwait on $2^{\text {nd }}$ August 1990; which led to the evacuation of 1,76,000 (Gateway House, 2017) Indians stranded in the region; the concern of the Indian Government was to immediately ensure a return of its citizens to India (Srijan Shukla, 2020). The Indian Government had initially used, Military aircraft to bring back its citizens, but found the difficulties of permission for Military aircrafts a task by itself, and called upon Air India and Indian Airlines with the Ministry of External Affairs (MEA) becoming the nodal agency to airlift stranded Indians. Besides the stranded Indians, the Indian Economy had been badly affected by the Kuwait crisis, on account of disruption of oil supply and foreign currency remittances by Indians employed in the Middle East (Agrawal and Aggarwal, 1992). Joint Secretary in the MEA, Mr KP Fabian was the point person who ensured coordination between Air India in coordination with Indian Airlines to operate 488 flights from Amman, Jordan from August $13^{\text {th }}$ to October $20^{\text {th }} 1990$. The 'Airlift' of 1990 is considered as one of the largest movements of human souls (Economic Times, 2017). (Note: Airlift, was the title of a Hindi Cinema who showcased the evacuation of stranded Indians from the Middle East. The main protagonist was Akshay Kumar, who emulated a combination of roles of the real-life hero's)

If the first Gulf War was a turning point in Indian Aviation history and business, maybe as a premonition, the Government of India in April 1990 had adopted "open-sky policy' and allowed Air Taxi Operators (ATO) to operate flights from any airport, both on a charter and a non-charter basis and also to decide their flight schedules, cargo and passenger fares (MoCA). It was the open-sky policy that ended the monopoly of Air-India and Indian Airlines, with private operators playing a dynamic role. However, as per the policy, no foreign airline could directly or indirectly hold equity in any Indian Domestic Airline entity. The repeal of the Air Corporation Act of 1953 in 1994 and the gradual increase in the number of passengers being ferried by the ATOs from 1990, ensured that private players were slow but steadily coming into the front of Indian Civil Aviation. 
Vol. 8, Issue 8, August 2021

DOI: $10.17148 /$ IARJSET.2021.8867

\begin{tabular}{|l|l|}
\hline Year & Numbers \\
\hline 1990 & 15,000 \\
\hline 1992 & 4.1 Lakhs \\
\hline 1993 & 29.2 Lakhs \\
\hline 1994 & 36 Lakhs \\
\hline 1995 & 48.9 Lakhs \\
\hline 1996 & 49.08 Lakhs \\
\hline
\end{tabular}

TABLE 4: Growth of Private Air carriers from 1990 to 1996 (Kimsexam, 2012)

The metric is clear that private players were here to stay and were using the best of opportunities to grow in a nascent market, that was thrown open for business. One aspect to note is that, by 1953, global aviation had already taken off in a big way. Starting in 1950, international air traffic grew in double digits every year till the first oil crisis of 1973 . It is sad, India missed the bus, nay, the flight due to its prolonged restrictive policies that were adopted in and from 1953. The growth rate of air traffic and connectivity was surely low till the resurgence occurred in the early nineties (Vishwajeet, Shelley, 2018).

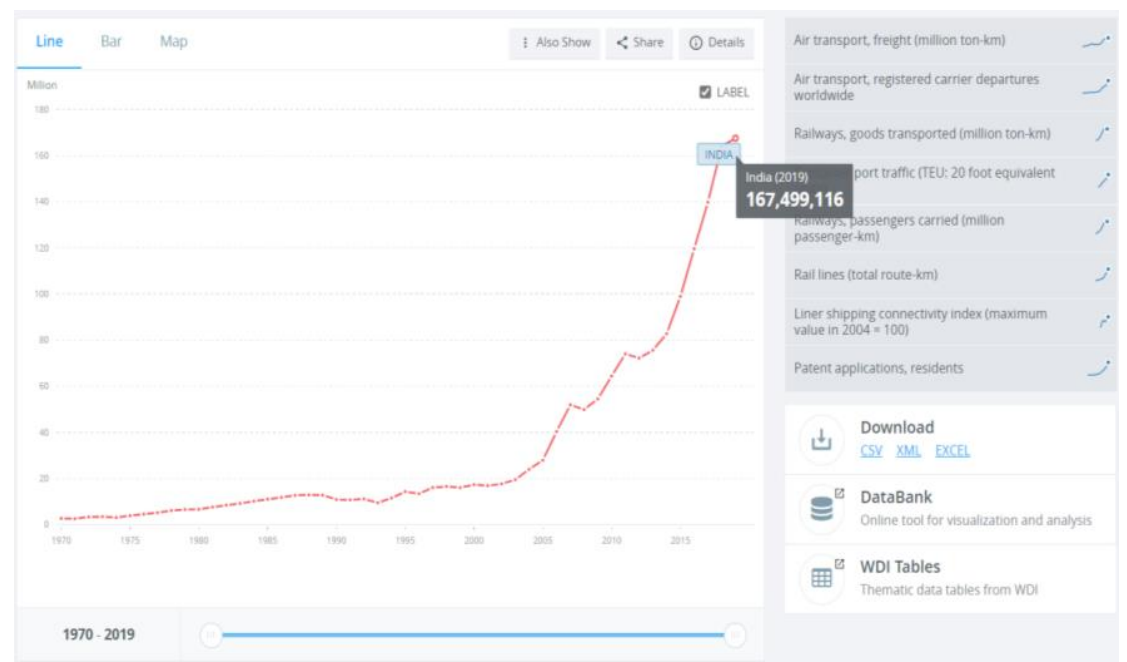

TABLE 5: Air transport, passengers carried - India (World Bank Data)

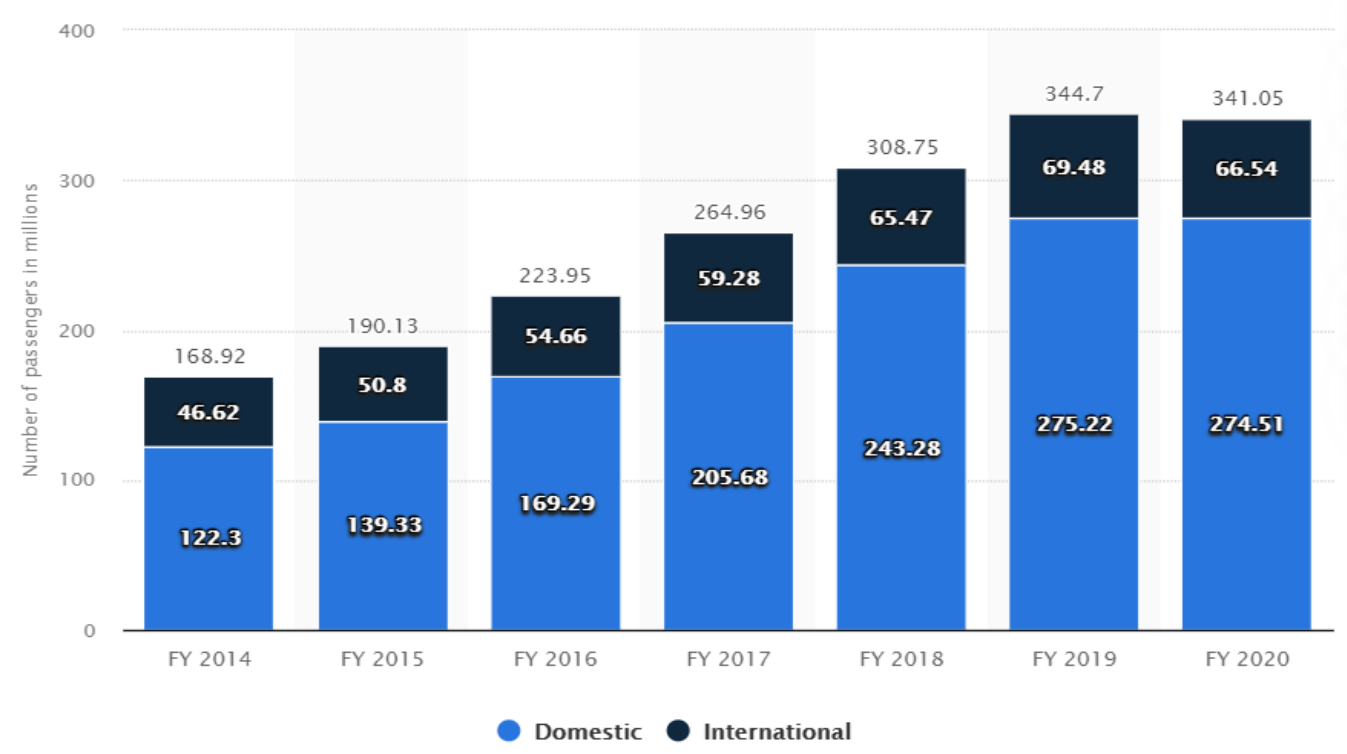

TABLE 6: Number of passengers handled at airports in India from the financial year 2014 to 2020 by type: Domestic and International (in Million) (Satistica 2020a) 


\section{International Advanced Research Journal in Science, Engineering and Technology}

Vol. 8, Issue 8, August 2021

DOI: $10.17148 /$ IARJSET.2021.8867

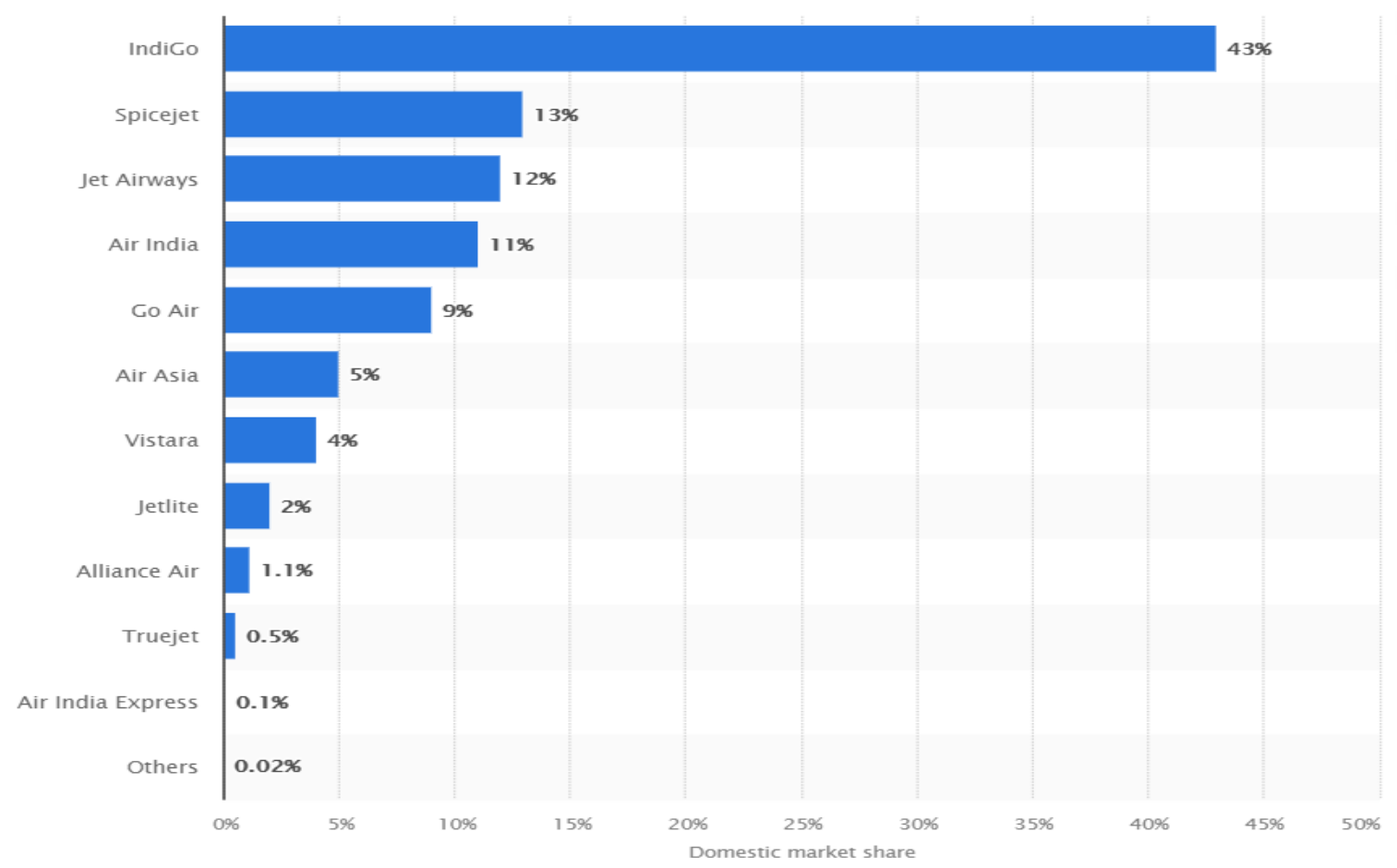

TABLE 7: Market share of airlines across India in the financial year 2019, by passengers carried. (Statistica, 2020b)

The metric from the table (7) is very clear the role being played by the Private Airlines in India, vis-à-vis the Governmentrun airlines. Private Airlines with a market share of $88.5 \%$ rule the roost in India in comparison to Air India, Alliance Air, Air India Express put together carried $12.2 \%$ of passenger traffic across the country in the year 2019. Not only the Private Airlines, but even the Government run enterprises were also making the best of efforts to stay alive and relevant in the Aviation business. It is the ability of the airlines, private and government through business combination, alliances, partnerships, acquisitions, mergers and JVs that the best of efforts was attempted, sometimes even for survival. The research paper will assess the methods adopted by TATA Sons and its partners, the combination of Air Indian and Indian Airlines along with other government affiliates, the Jet Airways conundrum, that no expert anticipated including Etihad of Abu Dhabi and the growth of Indigo and SpiceJet.

\section{TATA SONS AND ITS TRYST WITH AIRLINES}

We have seen the way Indian Aviation recognizes the work of JRD in bringing about a new business scoping, which lasted from 1932 till about 1977 when he was unceremoniously removed as Chairman by the PM Morarji, Government. From then on it was an uphill task for the TATAs to get to the business of civil aviation. Under the Prime Ministership of Inder Kumar Gujral, the TATAs were denied to start an Airline on account of the stubbornness of the Civil Aviation Minister, Mr CM Ibrahim as mentioned by MK. Kaw (2012), who was the Civil Aviation Secretary to the Government of India. Mr Kaw writes, "the history of civil aviation in this country would have taken a different trajectory, if TATA Singapore Airlines had been allowed to float an airline." (Deccan Herald, 20 ${ }^{\text {th }}$ April 2012). Even during the Prime Ministership of H.D. Deve Gowda, the Civil Aviation Ministers' contention that a foreign airline could not be permitted to hold equity in an Indian airline, leading to the TATA - Singapore Airline alliance and partnership being blocked, and at the same juncture Jet Airways which hell-bent on ensuring TATAs would not start an airline; had to shed its partners Kuwait Airways and Gulf Air who had to sell the 40\% stake they held in Jet Airways (Sudeep Chakravarti, 1998).

A: TATA Sons and AirAsia JV, an opportunity to get back to aviation

Despite all the issues the TATA group faced, there was redemption in 2013-2014 when the Ministry of Civil Aviation (MoCA), Government of India provided no-objection for the TATA Sons and Air Asia, Alliance, a partnership, a JV, that would bring the TATA group into the Aviation foray in India after it was taken away in 1953. The approval orders were music not only to the TATA Sons but to every aviation expert, the Tourism and Travel fraternity and even the common man of the TATA offering. 


\section{DOI: 10.17148/IARJSET.2021.8867}

Joint Venture of M/s Air Asia, TATA Sons and Telestra Tradeplace: Foreign Investment Promotion Bureau (FIPB) approved the proposal of M/s Air Asia to incorporate a new JV Company with a foreign equity of $49 \%$ amounting to US\$ 15 Million (INR 80,98,27,500/-) on $3^{\text {rd }}$ April 2013. The balance of 51\% equity is held in the ratio of $30 \%$ and $21 \%$ by M/s TATA Sons Limited and M/s Telestra Tradeplace Pvt. Ltd., respectively. M/s Air Asia India (P) Limited has been incorporated under the Companies Act as a JV of Air Asia Investment Lt., TATA Sons Ltd., and Telestra Tradeplace Pvt. Ltd., with the paid-up equity as INR 50 crore. The Company has applied for grant of permission to operate Scheduled Air Transport (Passengers) Services. After receipt of security clearance from the Ministry of Home Affairs, the Ministry of Civil Aviation (MoCA) has given a 'No objection Certificate' to M/s Air Asia to operate Scheduled Air Transport Services on $24^{\text {th }}$ September 2013. Operator permit issued by Directorate General of Civil Aviation (DGCA) on $7^{\text {th }}$ May 2014.

TABLE 8: MoCA orders on TATA Sons and Air Asia (MoCA, 2014-15)

The paid-up equity was clear from the MoCA orders:

\begin{tabular}{|l|l|l|}
\hline & Entity & Paid-up equity \\
\hline 1 & TATA Sons & $30 \%$ \\
\hline 2 & Telestra Tradeplace Pvt. Ltd., & $21 \%$ \\
\hline 3 & AirAsia & $49 \%$ \\
\hline
\end{tabular}

TABLE 9: AirAsia paid-up capital when the airline started

Once the Operators permit was issued on $7^{\text {th }}$ May 2014 by DGCA, it was clear that the TATA Sons was back into the Aviation business, through a JV with AirAsia Investment Limited (TATA.com 2021a). AirAsia India commenced operations on $12^{\text {th }}$ June 2014 with its headquarters in Bengaluru, India. AirAsia was owned by Tony Fernandes, who took over the assets of AirAsia a heavily indebted subsidiary of the Malaysian government-owned conglomerate along with Datuk Kamarudin Meranun for MYR 1 (USD 0.25) but also inherited the MYR 40 million debt (AirAsia, 2018) in September 2001 and became its CEO (Sharanjit Leyl, 2014). After acquiring the entity, Tony Fernandes transformed the company and even had an Initial Public Offering (IPO) in 2004, which was oversubscribed by 130\%. Then on AirAsia and its foray into the other countries and its acceptability as an LCC was itself a growth story.

In India, the TATA Sons were a trusted partner for AirAsia and ensured the brand reached out to the customers. By December 2019, AirAsia had a market share of 6.9\% (ET Bureau, 2021). This was the time when the pandemic had struck the world and it was playing on the economy. There were other issues too plaguing AirAsia, but the TATA Sons had infused INR 300 crores through a mix of equity and debt. By then it was clear that TATA Sons would not only rescue the airlines but also take up the stake of AirAsia in due course. By $29^{\text {th }}$ December 2020, AirAsia announced that they would be selling a $32.67 \%$ stake (490 million shares), to TATA Sons for $\$ 37.7$ Million (INR 280 crore), with a provision to sell its remaining $16.3 \%$ stake for $\$ 18.8$ million (INR 136.29 crore), which implied an equity valuation of INR 850 crore for the Bengaluru headquartered AirAsia (Giriprakash, K, 2021). TATA Sons has a ownership of 83.67\% in AirAsia and one can see the way TATA Sons have manoeuvred themselves in the airline industry cockpit through AirAsia, which will ensure success for them in the near and far future and yes, the dream of JRD, which was crushed in 1953, 1977 and the various obstacles placed by the Governments of the day, and even competition which ganged up against the TATAs is a clear indication that the Airline Industry will survive and better itself with the TATAs who are known for their ethical practices.

\section{B: TATA SONS AND SINGAPORE AIRLINES, A RELATIONSHIP TO CHERISH}

A good number of students, researchers and practitioners of the Aviation Industry in India, recall with panache, the way Singapore Airlines (SIA) and Cathay Pacific selected one of the best airlines of the world, to guide them in their formative years, and that was Air-India (Alikhan, 2017). KPMG's Amber Dubey, Partner and Head of Aerospace and Defence (till September 2019) (Mr. Amber Dubey is the Joint Secretary, Ministry of Civil Aviation, Government of India from September 2019) welcomed the announcement of a new full-service airline by the Tatas. He said, "this will open up competition in the westbound routes from India. Nearly $70 \%$ of global traffic from India is westbound - to the Middle East, European Union and Americas. With this JV, SIA gets a play in the growing international travel from India. SIA can also operate direct flights to the Far East and Australia from India or route them through Singapore" (Sindhu Bhattacharya, 2013). The TATA Sons vision ensured a qualitative relationship with SIA and the birth of a new Airline: Vistara. For any student and practitioner of Tourism and Aviation Management, it was clear that the TATA-SIA combination would provide for a phenomenal opportunity for growth and also create a value of significance to the Aviation business. 
The Ministry of Finance, Foreign Investment Promotion Bureau (FIPB) approved a proposal of TATA Sons Ltd., and Singapore Airlines Ltd., seeking permission for induction of foreign equity of Singapore Airlines Ltd., up to $49 \%$ in a JV Company to be established to engage in domestic and International Scheduled Air Transport (Passenger) Services in the Civil Aviation sector in India on $22^{\text {nd }}$ November 2013. After Receipt of security clearance from the Ministry of Home Affairs (MHA), the Ministry of Civil Aviation (MoCA) has given a 'No Objection Certificate' to M/s TATA SIA (TATA Sons and Singapore Airlines) to operate Scheduled Air Transport Services on $3^{\text {rd }}$ April 2014. Air Operator Permit has been issued to M/s TATA SIA Limited on $15^{\text {th }}$ December 2014.

TABLE 10: Orders of MoCA in regards to TATA - SIA approval (MoCA, 2014-15)

Better clarity of thought in regards to the JV, Alliance and partnership of TATA Sons and SIA comes about in the mention by Mukund Rajan, who was one of the TATA Sons nominees on board the proposed Airline. Mr Rajan, who is also part of the Centre for Asia Pacific Aviation (CAPA) as its Group Executive Council, mentioned that "based on CAPA data for 2012, the number of domestic airlines seats per capita is very low in India, just 0.07 ; this compares with 3.35 in Australia, 2.49 in the US, 1.38 for Canada and 1.05 for Japan. We would like to ensure that we can realise the original vision of launching a full-service world-class airline that India can be proud of." (Sharmistha Mukherjee, 2013).

Sharat Dhall, of Yatra.com a voice from the Online Travel Aggregators/Agencies (OTA) too worth observing, "This is a very welcome development considering that the air market in India is under-penetrated and has tremendous potential for growth. The additional capacity will help linking more cities as well as adding more seats on existing routes, thus growing the market by making air travel more affordable for the common man, wherein air travel would become more affordable." (Business World Online, 2014). It is by then clear, that the TATA-SIA launched its airline, Vistara, as a full-service carrier, based in Gurugram (earlier Gurgaon) with its hub at Indira Gandhi International Airport (IGI). It commenced its operations on $9^{\text {th }}$ January 2015 with its inaugural flight between New Delhi and Mumbai. By June 2015, Vistara had carried two million passen gers (SV Krishnamachari, 2016) and by May 2019 had a market share of $4.7 \%$ having carried 5.79 lakhs passengers (Rhik Kundu, 2019). It is clear here that, Vistara was slow but steadily making its presence felt in the India Aviation Space. A comparative il lustration will help the researcher and the reader to understand the state of Indian Civil Aviation in May 2019.

\begin{tabular}{|l|l|l|l|}
\hline & Airline & Market share & $\begin{array}{l}\text { The actual } \\
\text { number of } \\
\text { passengers }\end{array}$ \\
\hline 1 & IndiGo & $49 \%$ & 59.80 \\
\hline 2 & SpiceJet & $14.8 \%$ & 18.03 \\
\hline 3 & Air India & $13.5 \%$ & 16.53 \\
\hline 4 & GoAir & $11.1 \%$ & 13.55 \\
\hline 5 & AirAsia & $6.3 \%$ & 7.68 \\
\hline 6 & Vistara & $4.7 \%$ & 5.79 \\
\hline
\end{tabular}

TABLE 11: Passengers handled in May 2019 (Rhik Kundu, 2019)

Thence from Table (11), it is clear that the TATA Sons through its JV, Alliances and Partnerships had garnered close to $11 \%$ market share of the Indian Skies. With quality in the service offerings and connectivity. Fig. (11), will give a clearer picture of the JV, Alliances and Partnerships that TATA Sons as a group were able to create through AirAsia and SIA. The opportunities that they have, will surely and securely make them leaders in the aviation space. True, the timelines will be a point of debate; as to what will happen to competition and the way Airlines will function, the pandemic of 2019 has shown us a multitude of reasons to believe that, anything is possible; a failure, a turnaround, an alliance, a partnership, a little support from the Government of the day, passenger aircrafts being converted into Cargo flights, as did SpiceJet, and opened up a new business thought process. After the Government imposed a lockdown on $25^{\text {th }}$ March 2020, SpiceJet, handled 9,950 cargo flights till November 12 ${ }^{\text {th }}, 2020$, carrying 77,000 tonnes in total (Business Standard, 2020); an opportunity (Joshi, Ameya, 2021, read NOTE in references) and opening of new business. Hence, the TATAs also see a multitude of opportunities in collaboration and with the Air India bid (next segment), that TATAs are into; a behemoth, is clearly in the offing. If we are to look at Table (12) it is clear about the way the TATA group has created a network for itself within India and outside, which will lead to a further growth and development of the Aviation business for the group. 
Vol. 8, Issue 8, August 2021

DOI: $10.17148 /$ IARJSET.2021.8867

\begin{tabular}{|l|l|l|l|}
\hline Airline & Business Model & $\begin{array}{l}\text { Aircraft } \\
\text { fleet }\end{array}$ & Destinations \\
\hline SIA & Full Service & $\begin{array}{l}161 \text { (as on } 1^{\text {st }} \\
\text { July 2021) }\end{array}$ & $\begin{array}{l}130 \text { (Singapore } \\
\text { Airline, 2021) }\end{array}$ \\
\hline AirAsia & Low-cost & 34 & $20^{1}$ \\
\hline Vistara & Full Service & 47 & $\begin{array}{l}37 \text { (Wikipedia, } \\
2021)\end{array}$ \\
\hline
\end{tabular}

TABLE 12: The numbers, that lead towards profitability

With umpteen number of Codeshare (A code share flight is a flight that is marketed by one carrier and operated by another. Code share flights come about as a result of agreements between airlines to sell seats on each other's flights in order to provide passengers with a wider choice of destinations. The ticket would be booked on the flight number of the airline that you have booked your travel; however, it may be operated by another carrier. (https://www.airindia.in) and Interline (Interline is a relationship between airlines which allows one airline sells services to a customer that are provided by another airline. Airline's use interline framework to sell itineraries that they would otherwise not be able to serve alone. The IATA interline framework has been a cornerstone of the airline industry for almost as long as the industry has been operating. (https://www.iata.org) agreements that the three airlines have, it is clear that it is a win-win for the promoters, in this case, the TATA Sons. Thereby proving a point that the JVs, alliances, Partnerships promote value creation to the best of their ability.

\section{C: TATA SONS AND AIR INDIA, IS IT BACK TO THE FUTURE?}

JRD toiled from 1932 till 1953 when all of a sudden after years of entrepreneurship and encouraging others to take flight towards aviation; TATA Airlines was Nationalized. However, one face-saver the Government of the day did was to ensure JRD continued as Chairman of Air-India under the grip of the Government; till another Government of the day in New Delhi, pulled him out of the Leadership of Air-India and its affiliate in 1977. This in a way was the death knell for the airline and the ascendency of bureaucratic control and order that became the order of the day till the ramifications of privatising the behemoth became even more obvious. Till then JRD ensured the mantle of leadership that was given to him, made Air-India a successful entity, received global accolades for the services and became a household name.

JRDs remarks at the end of Air India's first annual general meeting seemed prophetic, “...Unless the greatest attention continues to be paid to the high standards of training and discipline amongst flying and ground crews, the resulting deterioration might destroy the good name of Indian civil aviation." Over the next twenty-five years, through personal commitment, he maintained high standards of service at Air India, which enjoyed an excellent reputation among passengers. JRD micromanaged the carrier's operational aspects. He would take great personal care of passengers, even when flying as a passenger himself. Many a time, he wandered about on flights, making notes of tiny details that needed to be fixed, from the level to which wine was poured into a wine glass to the hairstyle of air hostesses. If he saw a dirty airline counter, he would shame everyone by requesting a duster and wiping it himself. On one occasion, he rolled up his sleeves and helped the crew clean a dirty aircraft toilet (Shah, Shashank, 2018).

What happened to Air India and Indian Airlines over the years, is something one needs to capture in the life phases of the airline:

i) The Phase of TATA Airlines as TATA Air Services and later as TATA Airlines (1932 to 1946)

ii) $\quad 1946$ to 1953 , the Independence interregnum

iii) 1953 to 1977 , with JRD at the helm of Air-India and affiliates as Chairman

iv) Post 1977 the completely Government-run entity.

v) Post-1990, the Privatization era

As a research team, it is pertinent to note that phase (iv) is riddled with multiple happenings for the airlines which lead to many negative aspects in the growth scenario of an airline that enjoyed a monopoly in the country but still lost out because of its own doing.

Bhargava, Jitender (2013) mentions that the JRD transition over the years post his exit in 1977 is so tragic that from an era of meticulous planning Air India entered a phase where Murphy's Law, 'anything that can go wrong will go wrong,' became applicable in all aspects and facets to Air India. The Unions, the sudden change in livery branding, zero focus

\footnotetext{
${ }^{1}$ This is a list of current and confirmed prospective destinations that AirAsia and its subsidiaries Indonesia AirAsia, Thai AirAsia, Philippines AirAsia, AirAsia X, Thai AirAsia X and AirAsia India are flying to, as of July 2021.
} 


\title{
International Advanced Research Journal in Science, Engineering and Technology
}

\author{
Vol. 8, Issue 8, August 2021
}

\section{DOI: 10.17148/IARJSET.2021.8867}

on passenger loyalty, the competition in the 1990s, mismanaged priorities both from the bureaucracy and the political class, pilferage (of items like Whiskey), multiple departments, who never heeded to the feedback of the passengers, nepotism - but bringing in relatives and friends; clerical, secretarial and security staff being recruited as cabin crew, created a wedge that no one could fill. The Union of the airline, the administrative orders which were farcical in every which way, the Cabin Crew Movement Control Office issues, ensured the airline was evolving a scrouge, a Frankenstein, that would finish the airline of its vigour and vitalities. Acquisitions of aircraft made at the wrong time, too were much responsible for the financial decline of the airline. The merger (NACIL, 2013) of Air India and Indian Airlines and the creation of the National Aviation Company of India Ltd. (NACIL) and the creation of the brand name through Air India in 2007. Air India steadily slipped down the scale among international airline peers.

Such was the phenomena for Air India, which was consulted upon by a multitude of new airlines in its hey-days, was appearing more and more beleaguered and would have to walk on crutches if the Government of the day did not give out the doles at regular intervals.

Though on crutches, Air India always stood tall, when it served its nation at the time of need; whether it was the first gulf war and the evacuation of Indians and others in the 1990s, to the Vande Bharat Mission (VBM) flights following the Covid-19 lockdown, Air India (The Hindu, 2021) has operated 11,523 inbound flights to carry 18,19,734 passengers and 11,528 outbound flights and 13,68,457 passengers; Air India stood tall, when the Government of the day called for mission mode activity. This meant, that, Air India, could still be a successful entity, provided there was cohesion, but the accumulated losses are tearing into the economy of the airline. For the financial year 2020-2021 according to provisional figures shared by the Government in Lok Sabha, Air India is likely to incur a loss of INR 9,779 crores (The Hindu, 2021a).

The total debt of national carrier Air India as per provisional figures of 2019-20 (Apr-Mar) stands at Rs 38,366.39 crore. The total debt stands at Rs 38,366.39 crore after the transfer of debt amounting to Rs 22,064 crore to the special purpose vehicle called Air India Assets Holding Ltd in FY20. Simultaneously, MoCA said that the total net fixed assets of Air India as of March 2020 was worth Rs 45,863.27 crore. These include land and buildings, aircraft fleet and engines, other fixed assets, right-of-use assets and intangible assets (Anu Sharma, 2021).

A look back into the past measures of privatisation that the Government of India has taken will help one to understand where the airline or who the buyer would (on all accounts the street says, it will be the TATA Group) would take over. It was on $28^{\text {th }}$ June 2017, the Government of India approved the privatisation of Air India through a committee that was to start the process (BBC, 2017). An Expression of Interest (EoI) was issued in March 2018 to sell a $76 \%$ stake in Air India, along with LCC, Air India Express and a 50\% stake of AISATS, a ground handling JV with Singapore Airport Terminal Service (SATS). As per the EoI, the new owner would have to take a debt of INR 33,392 crore (USD 4.7 Billion) and the bid would have to by mid-May 2018, and if all was well, the sale would be through by end of 2018 (Mihir Mishra, 2018). But the story did not go as per the script as no private player was keen to take over a debt-ridden entity (Indian Express, 2018). It is at this juncture one realises that the Government of India had failed in its intent to sell off the ailing Air India, made a conscious decision to sell 100\% shares (Money Control, 2020) of Air India and its budget carrier, Air India Express and make ample preparations in 2019; 50\% of AISATS were also put on the block to attract bidders and had already decreased the debt to INR 30,000 crore (USD 4.2 Billion) of debts and liabilities to the SPV (Noronha, 2020).

Thence, from a scenario of a Minister in the Government commenting, "there are hardly any bakras (fools or scapegoats) around to buy the National Carrier," to Prof. Jitendra V. Singh's true statement of, "why do we have to go through this melodrama every few years? Is there serious interest in renewing the airline, or is this mere window dressing." (Knowledge @ Wharton, 2017), the Government of India has come a long way to ensure for as of $16^{\text {th }}$ July 2021 , the promoter of SpiceJet Ajay Singh is believed to have arranged USD 1 Billion as a war chest to bid for Air India through an SPV. It is believed that Mr Singh will be holding a minimum of 25\% share in the SPV, whilst close to USD 700 million will come from US funds (Business Today, 2021). To speak at ground zero, an employee of AISATS, who did not want to be identified, said, "we await the day, we will be rechristened as TATA - SATS; which will be the period of our glory."

TATA Sons - the holding entity of the \$113-billion salt-to-software conglomerate - recently roped in Bain and Company and Seabury Group to carry out due diligence on divestment-bound Air India and its subsidiary Air India Express (ET Now Digital, 2021) have been considered to be the best bet to win the bid for Air India as they have quoted a higher price than SpiceJet in the preliminary bidding round (Anirudh Laskar, 2021). It is clear that Air India has two bidders, the TATA Group and the Chairman of SpiceJet, Mr Ajay Singh and the Government is confident that by the first half of FY22, Air India will be, with a new owner. 


\title{
International Advanced Research Journal in Science, Engineering and Technology
}

\author{
Vol. 8, Issue 8, August 2021
}

\section{DOI: 10.17148/IARJSET.2021.8867}

\section{CONCLUSION}

It is clear from the research and the inputs that the researchers have collated, the TATA Group had made the best of efforts and ensured an airline that was dear to the country and the world. The quirk of fate had, it that, the political class and the bureaucracy ensured, that the TATA Group handed over the airline to the Government and an important corporate leader like JRD still oversaw the best of the airline. Air India created a niche for itself. The turn of events was the global political scene with the first Gulf War, which ensured played a dynamic role to bring back its citizens from the Middle East, which created a void in the aviation sector in India and also an opportunity for new entrants to come in. The private sector leadership ensured that the outreach from the Government was well received and many aviation start-ups came about but did not last long, till the market became mature and the best were able to survive for some time. Even at the growth stage of the aviation market in India, the TATAs were faced with an uphill task, either because of apathy from the political class or the obstinacy of the bureaucracy. The competitors, if we are to believe the readings that the researchers have seen, pleaded with the Governments of the day, not to permit the TATAs to come to the business of aviation. But the patience and perseverance that the TATAs had, ensured that they were able to tie up with SIA, create Vistara, and ensure a network with SIA itself, besides, the JV with AirAsia created one of the finest LCC in the continent; though the airline ran into rough weather for various reasons, and the TATAs were there to ensure. The current whiff of air is that the TATAs are in the right frame and position to take over the behemoth, started by the TATA group in 1932, which went into Government hands from 1946; Air India into the family of corporate entities within the TATA Sons; though the competition for the bid has been considered not to be as mighty as the TATAs. It is there clear that the TATAs who have constantly believed in value-creation through various means of Alliances, JV, acquisitions, mergers, partnerships have been able to hold on and ensure success as per the framework provided by Benjamin Gomes-Casseres. It is worthy to note that the TATA Group collaborated with Mercedes Benz from 1954; Starbucks JV from 2012; TATATimken enterprise in the Automotive Sector; TATA-Elxsi an Engineering and Designing Firm in the telecom and electronics space; in the 1980s the TATA Information System Ltd (TISL) which was later on renamed as TATA IBM; the TATA Hispano (Spain) for bus and coach manufacture; TATA and Marcopolo (Brazil) JV for bus manufacture; the TATA-Fiat alliance for Diesel engine and transmission technology; the TATA Hitachi Construction machinery JV; the TATA Harrier model is manufactured under a JV with Hyundai; the TATA Motors European Technical Centre for automotive design, engineering and research company are a few others to mention. They have ensured success in every walk of life in bringing about value-creation. Thence, the TATA foray into the aviation market of India and the world is surely ushering in the value-creation that every Manager in the domain of Strategic Management would vie for and ensure success. With a determined Government, making all efforts to sell Air India; the street and everyone else involved believe that TATA taking over Air India is the best outcome for all stakeholders (Anjuli Bhargava, 2021).

\section{ACKNOWLEDGMENT}

The heading of the Acknowledgment section and the References section must not be numbered. Causal Productions wishes to acknowledge Michael Shell and other contributors for developing and maintaining the IEEE LaTeX style files which have been used in the preparation of this template.

\section{REFERENCES}

[1]. APAO (2012), Report and Position papers: Chronology of event of Indian Civil Aviation Sector, Association of Private Airport Operators, https://www.apaoindia.com/?page_id=185 accessed and retrieved on $10^{\text {th }}$ July 2021

[2]. Agarwal, Devesh, (2011), Feature: Significant milestones in the 100 years of Indian Civil Aviation. https://www.bangaloreaviation.com/2011/02/feature-significant-milestones-in-100.html accessed and retrieved on $5^{\text {th }}$ July 2021

[3]. Agrawal, SP., and Aggarwal, JC., (1992), Information India 1990-91: Global View, Concept Publishing, New Delhi. ISBN: 9788170222934

[4]. AirAsia, (2018), Tony Fernandes, https://newsroom.airasia.com/leadership/2018/3/28/tony-fernandes accessed and retrieved on 12 July

2021

[5]. Alikhan, Anvar, Air India was once the company that inspired Singapore Airlines and Cathay Pacific, July $4^{\text {th }}$, 2017 https://qz.com/india/1021026/air-india-was-once-the-company-that-inspired-singapore-airlines-and-cathay-pacific/ accessed and retrieved on $5^{\text {th }}$ July 2021

[6]. Anirudh Laskar, Rhik Kundu, "TATAs firmly in the driver's seat to acquire Air India," Mint. $30^{\text {th }}$ April 2021. https://www.livemint.com/companies/news/tatas-firmly-in-the-driver-s-seat-to-acquire-air-india-11619774429116.html accessed and retrieved on $16^{\text {th }}$ July 2021

[7]. Anjuli Bhargava, "TATAs airline dilemma," Business Standard, 26 $6^{\text {th }}$ January 2021

[8]. Anu Sharma, “Air India's total debt stands at Rs. 38,366 crore as per FY20 Government data," CNBC TV. $3{ }^{\text {rd }}$ February 2021. https://www.cnbctv18.com/aviation/air-indias-total-debt-stands-at-rs-38366-crore-as-per-fy20-government-data-8198331.htm accessed and retrieved on $12^{\text {th }}$ June 2021

[9]. BBC, (2017), Air India Cleared for Privatisation by Delhi. https://www.bbc.com/news/business-40435922 accessed and retrieved on $1^{\text {st }}$ July 2021

[10]. Bhargava, Jitender, (2013), "The Descent of Air India, an insiders view of how a once globally cherished brand was grounded by those entrusted with the task of making it soar," Bloomsbury. ISBN: 9789384439729

[11]. Burns, F., John, (1997), Biju Patnaik, 81, Daring Pilot-Patriot of India, The New York Times,

https://www.nytimes.com/1997/04/21/world/biju-patnaik-81-daring-pilot-patriot-of-india.html accessed and retrieved on $12^{\text {th }}$ July $2021 . \quad$ NOTE: 


\title{
International Advanced Research Journal in Science, Engineering and Technology
}

\author{
Vol. 8, Issue 8, August 2021
}

\section{DOI: 10.17148/IARJSET.2021.8867}

Bijayananda (Biju) Patnaik, famous called the "Daring Pilot-Patriot of India" by John F. Burns in The New York Times found Kalinga Airlines with Calcutta (now Kolkata) as its primary base in 1947. It was a successful airline till all airlines were Nationalized in 1953, became a non-scheduled air service operator until it shut shop in 1972.

[12]. Business World Online, (2014), "Indian Aviation Market would turn into battle-field," Business World. $8^{\text {th }}$ November 2014. www.businessworld.in/article/Indian-Aviation-Market-Would-Turn-Into-Battle-field/08-11-2014-51564/ accessed and retrieved on 10 ${ }^{\text {th }}$ July 2021

[13]. Business Today, (2021), "SpiceJet promoter Ajay Singh to bid for Air India: prepares \$1bn war chest. Business Today. $16^{\text {th }}$ July 2021. https://www.businesstoday.in/industry/aviation/story/spicejet-promoter-ajay-singh-to-bid-for-air-india-prepares-1-bn-war-chest-301482-2021-07-16 accessed and retrieved on $16^{\text {th }}$ July 2021

[14]. Business Standard, (2013), The Tata's Flight story, Business Standard, $20^{\text {th }}$ February 2013. The story is available at: https://www.businessstandard.com/article/companies/the-tatas-flight-story-113022000585_1.html accessed and retrieved on $5^{\text {th }}$ July 2021

[15]. Business Standard, (2020), “SpiceJet handles 10,000 cargo flights since lockdown in late March,” Business Standard. $14^{\text {th }}$ November 2020. https://www.business-standard.com/article/pti-stories/spicejet-handles-10-000-cargo-flights-since-lockdown-in-mar-120111400948_1.html accessed and retrieved on $1^{\text {st }}$ July 2021

[16]. Deccan Herald, (2012), "New books tell how CM Ibrahim blocked TATA airline, Bangalore airport," Deccan Herald, 20 $0^{\text {th }}$ April 2012, https://www.deccanherald.com/content/243486/book-tells-c-m-ibrahim.html accessed and retrieved on $8^{\text {th }}$ July 2021

[17]. Economic Times, (2018), In next 6-8 months, we expect to gets bids Air India: Jayant Sinha. 9 ${ }^{\text {th }}$ January 2018, https://economictimes.indiatimes.com/markets/expert-view/in-next-6-8-months-we-expect-to-get-bids-for-air-india-jayant-

sinha/articleshow/62424407.cms_accessed and retrieved on $12^{\text {th }}$ June 2021.

[18]. ET Bureau, (2021), Covid-hit domestic airline passengers in 2020 similar to 2014-levels https://economictimes.indiatimes.com/industry/transportation/airlines-/-aviation/covid-hit-domestic-airline-passengers-in-2020-similar-to-2014-

levels/articleshow/80288119.cms?utm_source=contentofinterest\&utm_medium=text\&utm_campaign=cppst accessed and retrieved on $1^{\text {st }}$ July 2021

[19]. ET Network, (2017), "The man who inspired 'Airlift' is no more, here's his story," Economic Times, $22^{\text {nd }}$ May 2017. https://economictimes.indiatimes.com/news/politics-and-nation/the-man-who-inspired-airlift-is-no-more-heres-his-story/kp-

fabian/slideshow/58789712.cms accessed and retrieved on $1^{\text {st }}$ July 2021

[20]. ET Now Digital, (2021), “TATA has a challenger in SpiceJet's Ajay Singh for Air India sale," Times Now. 16 ${ }^{\text {th }}$ July 2021. https://www.timesnownews.com/business-economy/companies/article/tata-has-a-challenger-in-spicejets-ajay-singh-for-air-india-sale/785712 accessed and retrieved on $16^{\text {th }}$ July 2021

[21]. Gandhi, Forum, A year after shutting down operations, Jet Airways awaits new owners, The Hindu Business Line, 15 ${ }^{\text {th }}$ April 2020, https://www.thehindubusinessline.com/companies/a-year-after-shutting-down-operations-jet-airways-awaits-new-owners/article31347252.ece accessed and retrieved on $1^{\text {st }}$ July 2021

[22]. Gateway House (2017), Indian Council on Global Relations, Ambassador KP Fabian, https://www.gatewayhouse.in/author/k-fabian/ accessed and retrieved on $1^{\text {st }}$ July 2021

[23]. Giriprakash, K, “AirAsia India: An airline at crossroads," The Hindu Business Line, $21^{\text {st }}$ March $2021 . \quad$ The article can be read at: https://www.thehindubusinessline.com/specials/flight-plan/airasia-india-an-airline-at-crossroads/article34122908.ece accessed and retrieved on $14^{\text {th }}$ July 2021

[24]. Gomes-Casseres, Benjamin, (2015), Remix Strategy: the three laws of business combinations, Harvard Business School Publishing Corporation, USA. ISBN: 9781422163085

[25]. Gomes-Casseres, Benjamin, (2016), Making Mergers, Acquisition, and other Business Combinations work, Harvard Business Review, August 06, 2015, https://hbr.org/2015/08/making-mergers-acquisitions-and-other-business-combinations-work

[26]. Indian Express, (2018), With no buyers for Air India, Modi Government may be open to listing airline on stock market. https://indianexpress.com/article/business/with-no-buyers-for-air-india-modi-government-considers-listing-it-on-stock-market-5216046/ accessed and retrieved on $16^{\text {th }}$ July 2021

[27]. India Today (2016) Web Desk, World's first official airmail sent from Allahabad to Naini on February 18, 1911: Interesting facts. https://www.indiatoday.in/education-today/gk-current-affairs/story/worlds-first-official-airmail-309327-2016-02-18_1th 1st June 2021

[28]. Joshi, Ameya, (2021), Spicejet is flying on cargo and a prayer, https://www.moneycontrol.com/news/business/spicejet-is-flying-on-cargoand-a-prayer-7133191.html accessed and retrieved on $15^{\text {th }}$ July 2021 (NOTE: SpiceJet Cargo Operations: The Lockdown ensured a new business opportunity and as of November 2020, SpiceJet became the first and only India Carrier to operate a non-stop cargo service from Europe (Amsterdam) to New Delhi through the A340 freighter Aircraft. Now SpiceJet has a total of twenty freighter aircrafts to service a new offering to the world of business. The Revenue for SpiceJet jumped 518\% to INR 1,117.5 crore, most of which came from Cargo, a business that SpiceJet would like to hive off as a separate entity)

[29]. Kaw, Maharaj Krishen, (2012), An Outsider everywhere, Revelations by an insider, Konark Publishers, ISBN: 9789322008048

[30]. Kimsexam, (2012), Open sky policy and current scenario, $16^{\text {th }}$ January 2012, Airlines and Airport Management, Open Sky Policy and Current scenario (kimsexam2012.blogspot.com) Article available on http://kimsexam2012.blogspot.com/2012/01/open-sky-policy-currentscenario.html accessed and retrieved on $7^{\text {th }}$ July 2021.

[31]. Knowledge @ Wharton, (2017), Privatizing Air India: Is the Price too high,” https://knowledge.wharton.upenn.edu/article/privatizing-airindia-price-high/ accessed and retrieved on $10^{\text {th }}$ July 2021

[32]. Wickstead, Maurice, (2016), Air India Part 2. April 2016

[33]. Mihir Mishra, "Government invites bids to sell 76\% stake in Air India," Economic Times, $29^{\text {th }}$ March 2018. https://economictimes.indiatimes.com/industry/transportation/airlines-/-aviation/government-calls-out-bids-to-sale-76-per-cent-stake-in-air-

india/articleshow/63517638.cms?from=mdr accessed and retrieved on $16^{\text {th }}$ July 2021

[34]. MoCA, News about the functioning. Accessed and retrieved on $2^{\text {nd }}$ June 2021 https://www.civilaviation.gov.in/en/news/directorate-generalcivil-aviation

[35]. Ministry of Civil Aviation (MoCA), Government of India (GoI), Annual Report 2003-04, https://www.civilaviation.gov.in/sites/default/files/Annual\%20Report\%20-\%202003-2004.pdf accessed on 1st July 2021

[36]. Ministry of Civil Aviation (MoCA), Government of India (GoI), Annual Report 2014-15, Enabling Connectivity https://www.civilaviation.gov.in/sites/default/files/annual_report-2014_15_eng.pdf accessed on 1st July 2021

[37]. Money Control (2020), Air India Sale: EoI out, Govt to completely exit airline. https://www.moneycontrol.com/news/business/companies/air-india-eoi-out-govt-to-completely-exit-airline-4860691.html accessed and retrieved on $12^{\text {th }}$ July 2021

[38]. NDA (2016), The Indian Aviation Sector, August 2016, Nishith Desai Associates (Legal and Tax Counselling Worldwide) document can be downloaded at www.nishithdesai.com/fileadmin/user_upload/pdfs/Research\%20Papers/The_Indian_Aviation_Sector.pdf_accessed and retrieved on $12^{\text {th }}$ July 2021

[39]. National Park Service, USA, https://www.nps.gov/wrbr/index.htm accessed and retrieved on $5^{\text {th }}$ July 2021 


\title{
International Advanced Research Journal in Science, Engineering and Technology
}

\author{
Vol. 8, Issue 8, August 2021
}

\section{DOI: $10.17148 / I A R J S E T .2021 .8867$}

[40]. NACIL, (2013), National Aviation Company of India Ltd., Integrity Pact Program. https://www.webcitation.org/6G1QZJ2YV?url=http://mmd.airindia.co.in/aimmd/tender/Integrity_Pact_brief.pdf accessed and retrieved on 16 ${ }^{\text {th }}$ July 2021

[41]. Noronha, Peter, (2020), "For 100\% sale of Air India, March 17 deadline, for bids: 10 points," NDTV. 27 January 2020. https://www.ndtv.com/business/government-invites-bids-for-100-per-cent-stake-sale-in-air-india-2170124 accessed and retrieved on $15^{\text {th }}$ July 2021

[42]. Pal, Sanchari, (2017) The little-known story of the first Air India flight in 1932, and the legendary man piloting it. March, $23^{\text {rd }}$, 2017 https://www.thebetterindia.com/92669/air-india-jrd-tata-airlines-karachi-bombay/ access and retrieved on $4^{\text {th }}$ July 2021

[43]. Pranjoy Guha Thakurta, "Government opens up the skies for private air taxis," India Today, 15 ${ }^{\text {th }}$ May 1990. The article can be read at: https://www.indiatoday.in/magazine/economy/story/19900515-government-opens-up-skies-for-private-air-taxis-812565-1990-05-15 accessed and retrieved on $9^{\text {th }}$ July 2021

[44]. Rhik Kundu, "India's domestic air traffic grows 3\% in May after registering a fall in April," Mint, 18 ${ }^{\text {th }}$ June 2019, https://www.livemint.com/companies/news/india-s-domestic-air-traffic-grows-3-in-may-after-registering-a-fall-in-april-1560858888397.html accessed and retrieved on $9^{\text {th }}$ July 2021

[45]. SV Krishnamachari, "Vistara looking at Strategic Partnerships to expand the business," The International Business Times, $17^{\text {th }}$ June 2016, https://www.ibtimes.co.in/vistara-looking-strategic-partnerships-expand-business-683235 accessed and retrieved on $14^{\text {th }}$ July 2021

[46]. Shah, Shashank, (2018), The TATA Group, from Torchbearers to Trailblazers, Penguin, ISBN: 9780670090679

[47]. Sharanjit, Leyl, “Tony Fernandes: The man behind AirAsia's revival," $28^{\text {th }}$ December 2014, https://www.bbc.com/news/business-30615450 accessed and retrieved on $13^{\text {th }}$ July 2021

[48]. Sharmistha Mukherjee, "Domestic airfares likely to come down with capacity addition by TATA-Singapore Airlines," $24^{\text {th }}$ September 2013. https://www.business-standard.com/article/companies/domestic-air-fares-likely-to-come-down-with-capacity-addition-by-tata-singapore-airlines-

113092001003 1.html accessed and retrieved on $15^{\text {th }}$ July 2021

[49]. Sindhu Bhattacharya, "Why TATA Sons chose Singapore Airlines to launch new carrier in India," The First Post, $20^{\text {th }}$ September 2013. https://www.firstpost.com/business/why-tata-sons-chose-singapore-airlines-to-launch-new-carrier-in-india-1120819.html accessed and retrieved on 14th July 2021

[50]. Singapore Airline, (2021). Where we fly, https:/www.singaporeair.com/en_UK/sg/plan-travel/destinations/where-we-fly/ accessed and retrieved on $15^{\text {th }}$ July 2021

[51]. Srijan Shukla, "Three decades before Covid, India conducted the largest civilian evacuation in history," The Print, $7^{\text {th }}$ May 2020. https://theprint.in/india/three-decades-before-covid-india-conducted-the-largest-civilian-evacuation-in-history/416095/ accessed and retrieved on $8^{\text {th }}$ July 2021

[52]. Statistica, (2020a), Number of passengers handled at airports in India from financial year 2014 to 2020 by type (Date of release of inputs and information: May 2020): Domestic and International accessed through freely available resource at Statistica (www.statistica.com) https://www.statista.com/statistics/588028/passengers-boarded-by-type-by-indian-air-carriers/ on $6^{\text {th }}$ July 2021

[53]. Statistica, (2020b), Market share of airlines across India in financial year 2019, by passengers carried. (Date of release of inputs and information: January 2020): Accessed through freely available resource at Statistica (www.statistica.com) https://www.statista.com/statistics/575207/air-carrier-india-domestic-market-share/ on $7^{\text {th }}$ July 2021

[54]. Sudeep Chakravarti, “Tripped by politics and intense lobbying, TATA Group's airline project falls apart,” India Today, 20 July 1998. https://www.indiatoday.in/magazine/economy/story/19980727-tripped-by-politics-tata-group-airline-project-falls-apart-826792-1998-07-20 7th July 2021

[55]. TATA.com (2021), Wings for a Nation, https://www.tata.com/newsroom/wings-for-a-nation accessed and retrieved 3rd July 2021

[56]. TATA.com (2021a), AirAsia (India) https://www.tata.com/business/air-asia-india accessed and retrieved on $15^{\text {th }}$ July 2021

[57]. The Hindu (2021), Vande Bharat becomes one of top civilian evacuations https://www.thehindu.com/news/national/vande-bharat-becomesone-of-top-civilian-evacuations/article34361996.ece accessed and retrieved on $15^{\text {th }}$ July 2021

[58]. The Hindu (2021a), Air India likely to incur loss of almost Rs. 10,000 cr. https://www.thehindu.com/business/air-india-likely-to-incur-lossof-almost-10000-cr/article34164016.ece accessed and retrieved on $13^{\text {th }}$ July 2021

[59]. Vishwajeet, Shelley, (2018), The IndiGo Story, inside the upstart that redefined Indian Aviation, Rupa, New Delhi. ISBN: 9789353043551

[60]. Wikipedia (2021), https://en.wikipedia.org/wiki/Vistara accessed and retrieved on $15^{\text {th }}$ July 2021

[61]. World Bank Data, Air Transport, passengers carried - India, International Civil Aviation Organization (ICAO), Civil Aviation Statistics of the World and ICAO Staff actimates data https://data. worldbank.org/indicator/IS.AIR.PSGR?end=2019\&locations=IN\&start=1970\&view=chart on $8^{\text {th }}$ July 2021

\section{BIOGRAPHY}

\section{Author 1: Shaheed Khan}

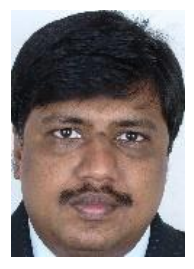

Academically qualified in the areas of and armed with Post Graduate Degrees in History, Tourism, Business Administration and Law; Shaheeds' focus area has been Tourism, Services, Mergers and Acquisitions and Human Resources. He also has a Micro-specialization in Strategy Management from Indian Institute of Management Kozhikode and a Corporate Program in Leadership Management from Harvard School of Publishing. He brings to the table multiple facets of functioning that supports in any area of academics and practice in the corporate world. Having worked in the Government, Private and Social Sectors, Shaheed has got to broad understanding of Tourism, Travel and Hospitality (TTH). Besides being a Doctoral Research Scholar at CTHM, Madurai Kamaraj University, Madurai, Shaheed is the Director for Training and Research with Dharthi NGO, Bangalore. He is also an Adjunct Faculty for a Leading Deemed to be University, and engages Class session for Corporates in Leading IT and manufacturing Companies of India. Email: 


\title{
International Advanced Research Journal in Science, Engineering and Technology
}

\author{
Vol. 8, Issue 8, August 2021
}

DOI: $10.17148 /$ IARJSET.2021.8867

\section{Author 2: Freeda Maria Swarna M.}

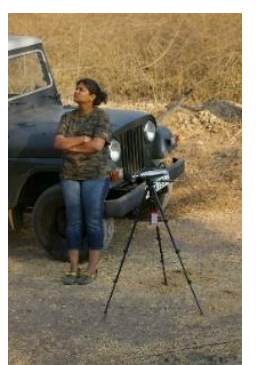

Over 15 years of experience in the Sustainability, Conservation Science, Environment, Communities and Tourism domains. My strength lies in combining Applied Sciences and the integration of sound research with robust implementation. Through Dharthi (NGO), our suggestions have been included in Government dossiers and reports for better management of tourism and communities for sustained livelihoods, and contributed towards policy decisions in the Ecotourism sector, that is inclusive and sustainable. Extensive field knowledge (Pan India) and thorough understanding of the government's laws and rules including the schemes and programmes in my field of work is my strength. Strategic Planning, programme management, stakeholder collaborations, community engagements, impact investing, Social, Environment and Tourism Impact Assessments are my interests. Through the works with the Forest Departments of Karnataka, Tamil Nadu, Maharashtra and Madhya Pradesh, our presence remains. Dharthi, was nominated to the Karnataka Ecotourism Development Board as member of the General Body, during the three-year tenure, I was instrumental in conducting Cumulative Impact assessment (CIA) studies, have consultations with stakeholders for a robust Ecotourism Policy for the State. Freeda is in the process of authoring two books, one on Ecotourism, and have published articles and papers to my credit. My penchant for writing, I am in the process of putting up my blogsite called https://highwaymybeckoning.com, that will have impactful stories of my travels, people and places. She is a Doctoral Research Scholar at CTHM, Madurai Kamaraj University, Madurai in the domain area of Tourism.

\section{Author 3: R. Kannan}

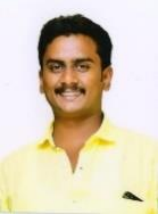

With more than three decades of teaching and two decades of Research experience, Dr. R. Kannan, is the Professor and Director of the Centre for Tourism and Hotel Management (CTHM), Madurai Kamaraj University, Madurai. Besides PhD in Tourism Management, Prof. Kannan has three Post Graduate Degrees and Diploma in French and Teacher Training in Hotel Management. He has been the Supervisor for 13 Researchers, and 9 are in the to be submitted in due course. He has close to 100 research publications to his credit and presented pa Research papers in a multitude of Seminars and Conferences.

\section{Author 4: S. Praveen Kumar}

With a decade of teaching and research experience, besides nine years in the tourism industry, Dr. Praveen has successfully supervised six PhD students and is guiding thee at present. His specialization areas of Services Marketing, Tourism Management and Entrepreneurship helps him to engage with the various aspects of Tourism and Travel Management and bring the best out for the business of Travel. His research abilities have ensured that the best reaches out to the academia and the practitioner. His research papers been selected for best research papers many a time. 